\title{
Intestinal parasitic infection among mentally handicapped students in the Islamic Republic of Iran
}

Maryam Khedri, ${ }^{1}$ Mina Piri ${ }^{1}$ and Mohammad Matini ${ }^{2}$

${ }^{1}$ Students Research Center, Hamadan University of Medical Sciences, Hamadan, Islamic Republic of Iran. ${ }^{2}$ Department of Medical Parasitology and Mycology, School of Medicine, Hamadan University of Medical Sciences, Hamadan, Islamic Republic of Iran (Correspondence to: Mohammad Matini: matini@umsha.ac.ir; matini.mohammad@yahoo.com).

\begin{abstract}
Background: Intestinal parasitic infections are among the most common public health problems in populations with poor hygiene. Consequently, mental retardation increases the risk of infection.

Aims: The aim of this study was to investigate the prevalence of intestinal parasitic infections among mentally disabled young people in Hamadan, western Islamic Republic of Iran.

Methods: This descriptive cross-sectional study was conducted on 318 students in 9 special schools in 2017. Triplicate faecal specimens for each student were subjected to stool analysis using direct wet mount, sedimentation concentration, and permanent staining technique. Chi-squared or Fisher's exact test were used for statistical analysis.

Results: Out of 318 students, 135 (42.5\%, 95\% CI: 37.1-47.9) were infected with intestinal parasites. Prevalence rates for females and males were $45.2 \%(61 / 135)$ and 40.4\% (74/183) respectively. Protozoan infections (42.5\%, 135) were more numerous than helminthiasis $(0.6 \%, 2)$. Blastocystis hominis $(28 \%, 89)$ was the most common parasite, followed by Giardia lamblia (9.7\%, $31)$, Entamoeba coli $(9.1 \%, 29)$ and Trichomonas hominis $(6 \%, 19)$.

Conclusions: The high prevalence rate of intestinal protozoan infection reflects poor personal hygiene among the students and inappropriate environmental conditions. Therefore, specific public health measures are required for the mentally handicapped students in special schools.

Keywords: intestinal parasitic infections, mentally disabled persons, students, prevalence, Iran

Citation: Khedri M; Piri M; Matini M. Intestinal parasitic infection among mentally handicapped students in Hamadan, Islamic Republic of Iran. East Mediterr Health J. 2021;27(9):868-873. https://doi.org/10.26719/emhj.21.039

Received: 16/07/19; accepted: 01/03/21

Copyright (c) World Health Organization (WHO) 2021. Open Access. Some rights reserved. This work is available under the CC BY-NC-SA 3.o IGO license (https://creativecommons.org/licenses/by-nc-sa/3.o/igo).
\end{abstract}

\section{Introduction}

Parasite infection still strongly influences the lives of humans. Their major impact is seen in developing countries, and especially in vulnerable groups. It is estimated that 3.5 billion people are affected and 450 million are sick worldwide as a result of intestinal parasitic infections (IPIs) (1). The economic burden is significant: they are responsible for a loss of around 35.4 million disability adjusted life years annually. In addition to gastrointestinal symptoms and digestive disorders, IPIs can cause micronutrient deficiency, mental and physical growth retardation and other serious health problems in children (2-4). Nonpathogenic parasites do not cause sickness and some parasitic pathogens may cause asymptomatic or mildly symptomatic infection in immunocompetent hosts. Therefore, these infections have been overlooked in high-risk groups (5).

Intestinal parasites are transmitted via the faecaloral route, through unsafe drinking water and food and direct contact with contaminated soil and infected people. Low socioeconomic conditions and poor personal hygiene are believed to be the main epidemiological factors in the spread of IPIs in a society $(4,6,7)$. The high incidence of infections among mentally disabled persons is predictable owing to inadequate personal hygiene. Indeed, IPIs are one of the major problems in the management of rehabilitation centres for mentally disabled persons, and mental disability can be considered another risk factor for intestinal infections, especially for parasitic infections (8).

There have been several reports of IPIs in people with disabilities from different parts of the country (9-13), but to our knowledge, there is little information about the infections in people with disabilities in Hamadan province. Therefore, considering the importance of IPIs in school-aged individuals with disabilities, this study was conducted to evaluate the prevalence of IPIs and their epidemiological associations among the students in special schools in Hamadan.

\section{Methods}

\section{Patients and study area}

Hamadan, the capital city of Hamadan province, is located in the western region of the country, with a population of over 676105 and an area of 2831 square kilometres. This city lies at $48^{\circ} 32^{\prime} \mathrm{E}$ and $34^{\circ} 51^{\prime} \mathrm{N}$ and at an altitude of 1850 metres. The region has an average annual temperature of $13.4{ }^{\circ} \mathrm{C}$ and average annual precipitation is 308 $\mathrm{mm}$ (data from the Statistical Centre of Iran: https:// www.amar.org.ir). 
This cross-sectional study was conducted in 9 special schools for students with intellectual disability, including primary and high schools, from January to July 2017 in Hamadan. All of the students, 530 individuals, were enrolled in the study.

\section{Ethical considerations}

Before the start of the study, informed consent was obtained from the students' parents. This study was approved by the research ethics committee of the Hamadan University of Medical Sciences (Ref. Number: 16.35.1.5168)

\section{Sample collection and examination}

Interviews were conducted by trained teachers. Parents answered sociodemographic questions regarding age, sex, parents' education, residence status, and method of washing vegetables. Then, stool specimens were collected every other day (total 3 specimens) because of the intermittent nature of parasite shedding (14). The stool specimens were transferred to the parasitology research laboratory of Hamadan University of Medical Sciences and tested by complete ova and parasite examination
(15). After macroscopic examination, the samples were subjected to microscopic examination: direct wet smear (saline and Lugol's iodine preparation), formalin-ethyl acetate concentration, and trichrome permanent stained smear (15). Those students found to be infected were referred to health centres for treatment.

\section{Statistical analysis}

Statistical data analysis was performed using SPSS, version 16 , and chi-squared $\left(\chi^{2}\right)$ or Fisher's exact tests. $P$-value $<0.05$ was considered statistically significant.

\section{Results}

Of the 530 students in total, 318 remained in the study; the others were excluded because of incomplete information or improper sample collection. The age of the participants ranged from 7 to 18 years; 183 (57.5\%) were males and $135(42.5 \%)$ were females.

We found that 135 of the students $(42.5 \%, 95 \% \mathrm{CI}$ : $37.1-47.9 \%)$ were parasitized by intestinal protozoa and helminths, prevalence $42.5 \%(n=135)$ and $0.6 \%(n=2)$ respectively. Sociodemographic characteristics of the

\begin{tabular}{|c|c|c|c|c|}
\hline \multirow[t]{2}{*}{ Demographic characteristics } & \multirow{2}{*}{$\begin{array}{c}\text { Total } \\
\text { No. (\%) }\end{array}$} & \multicolumn{2}{|c|}{ Students } & \multirow[t]{2}{*}{ P-value } \\
\hline & & $\begin{array}{c}\text { Infected } \\
\text { No. }(\%)\end{array}$ & $\begin{array}{c}\text { Uninfected } \\
\text { No. }(\%)\end{array}$ & \\
\hline Age (years) & & & & 0.002 \\
\hline $7-12$ & $190(100)$ & $67(35.3)$ & $123(64.7)$ & \\
\hline $13-18$ & $128(100)$ & $68(53.1)$ & $60(46.9)$ & \\
\hline Sex & & & & 0.397 \\
\hline Male & $183(100)$ & $74(40.4)$ & $109(59.6)$ & \\
\hline Female & $135(100)$ & $61(45.2)$ & $74(54.8)$ & \\
\hline Mother's education $^{a}$ & & & & 0.292 \\
\hline Illiterate & $60(100)$ & $32(53.3)$ & $28(46.6)$ & \\
\hline Primary school & $80(100)$ & $37(46.3)$ & $43(53.7)$ & \\
\hline Junior high school & $57(100)$ & $24(42.1)$ & $33(57.9)$ & \\
\hline Senior high school & $26(100)$ & $8(30.8)$ & $18(69.2)$ & \\
\hline University & $10(100)$ & $3(30)$ & $7(70)$ & \\
\hline Father's education ${ }^{a}$ & & & & 0.027 \\
\hline Illiterate & $54(100)$ & $33(61.1)$ & $21(38.9)$ & \\
\hline Primary school & $54(100)$ & $27(50)$ & $27(50)$ & \\
\hline Junior high school & $65(100)$ & $25(38.5)$ & $40(61.5)$ & \\
\hline Senior high school & $37(100)$ & $11(29.7)$ & $26(70.3)$ & \\
\hline University & $20(100)$ & $8(40)$ & $12(60)$ & \\
\hline Residencea & & & & 0.21 \\
\hline Urban & $203(100)$ & $87(42.8)$ & $116(87.1)$ & \\
\hline Rural & $29(100)$ & $16(55.2)$ & $13(44.8)$ & \\
\hline Method of washing vegetables ${ }^{a}$ & & & & 0.002 \\
\hline Water & $70(100)$ & $43(61.4)$ & $27(38.6)$ & \\
\hline Detergent solution & $109(100)$ & $45(41.3)$ & $64(58.7)$ & \\
\hline Disinfectant solution & $52(100)$ & $16(30.8)$ & $36(69.2)$ & \\
\hline
\end{tabular}

a Data analysis was conducted on 232 participants who had fully answered the questions. 


\begin{tabular}{|c|c|c|}
\hline $\begin{array}{l}\text { Multiplicity } \\
\text { of infection }\end{array}$ & $\begin{array}{c}\text { Parasite species (cyst, trophozoite } \\
\text { \& ova) }\end{array}$ & No. $(\%)$ \\
\hline \multirow[t]{8}{*}{ Single } & & $96(30.2$ \\
\hline & Blastocystis hominis & $55(17.3)$ \\
\hline & Giardia lamblia & $20(6.3)$ \\
\hline & Trichomonas hominis & $9(2.8)$ \\
\hline & Entamoeba coli & $7(2.2)$ \\
\hline & Iodamoeba butschlii & $3(0.9)$ \\
\hline & Dientamoeba fragilis & $1(0.3)$ \\
\hline & Endolimax nana & $1(0.3)$ \\
\hline \multirow[t]{9}{*}{ Double } & & $25(7.9)$ \\
\hline & Blastocystis hominis + Entamoeba coli & $7(2.2)$ \\
\hline & Blastocystis hominis + Trichomonas hominis & $6(1.9)$ \\
\hline & Blastocystis hominis + Giardia lamblia & $5(1.6)$ \\
\hline & Blastocystis hominis + Iodamoeba butschlii & $3(0.9)$ \\
\hline & Blastocystis hominis + Dientamoeba fragilis & $1(0.3)$ \\
\hline & Entamoeba coli + Giardia lamblia & $1(0.3)$ \\
\hline & Entamoeba coli + Iodamoeba butschlii & $1(0.3)$ \\
\hline & Entamoeba coli + Endolimax nana & $1(0.3)$ \\
\hline \multirow[t]{9}{*}{ Triple } & & $10(3.1)$ \\
\hline & $\begin{array}{c}\text { Giardia lamblia + Entamoeba coli + } \\
\text { Endolimax nana }\end{array}$ & $1(0.3)$ \\
\hline & $\begin{array}{c}\text { Giardia lamblia + Blastocystis hominis + } \\
\text { Iodamoeba butschlii }\end{array}$ & $1(0.3)$ \\
\hline & $\begin{array}{c}\text { Giardia lamblia + Blastocystis hominis + } \\
\text { Entamoeba coli }\end{array}$ & $1(0.3)$ \\
\hline & $\begin{array}{c}\text { Giardia lamblia + Blastocystis hominis + } \\
\text { Dicrocoelium dendriticum }\end{array}$ & $1(0.3)$ \\
\hline & $\begin{array}{c}\text { Blastocystis hominis + Entamoeba coli + } \\
\text { Trichomonas hominis }\end{array}$ & $3(0.9)$ \\
\hline & $\begin{array}{l}\text { Blastocystis hominis + Entamoeba coli + } \\
\text { Chilomastix mesnili }\end{array}$ & $1(0.3)$ \\
\hline & $\begin{array}{c}\text { Blastocystis hominis + Entamoeba coli + } \\
\text { Iodamoeba butschlii }\end{array}$ & $1(0.3)$ \\
\hline & $\begin{array}{c}\text { Blastocystis hominis + Entamoeba coli + } \\
\text { Ascaris lumbricoides }\end{array}$ & $1(0.3)$ \\
\hline \multirow[t]{5}{*}{ Quadruple } & & $4(1.3)$ \\
\hline & $\begin{array}{l}\text { Entamoeba coli + Blastocystis hominis + } \\
\text { Iodamoeba butschlii + Giardia lamblia }\end{array}$ & $1(0.3)$ \\
\hline & $\begin{array}{l}\text { Entamoeba coli + Blastocystis hominis + } \\
\text { Iodamoeba butschlii + Endolimax nana }\end{array}$ & $1(0.3)$ \\
\hline & $\begin{array}{l}\text { Entamoeba coli + Blastocystis hominis + } \\
\text { Iodamoeba butschlii + Trichomonas hominis }\end{array}$ & $1(0.3)$ \\
\hline & $\begin{array}{c}\text { Entamoeba coli + Endolimax nana } \\
\text { + Iodamoeba butschlii + Entamoeba } \\
\text { hartmanni }\end{array}$ & $1(0.3)$ \\
\hline
\end{tabular}

participants are presented in Table 1. The associations between IPIs and age, father's education, method of washing vegetables were statistically significant.
The prevalence rates for parasites are listed in Table 2. Mono- and polyparasitism rates were $30.2 \%$ (96) and $12.3 \%$ (39), respectively. Thirty-three of the students (10.4\%) harboured pathogenic intestinal parasites and 102 (32.1\%) were infected with nonpathogenic parasites. Blastocystis hominis was the most common intestinal parasite with an overall prevalence of $28 \%$ (89 cases) compared with 0.3\% (1 case) for both Ascaris lumbricoides and Dicrocoelium dendriticum.

\section{Discussion}

Intestinal parasitic infections constitute a major public health concern globally. The infections are often associated with certain socioeconomic factors such as poverty, high population density, lack of access to health facilities and poor personal hygiene. Epidemiological survey of IPIs is necessary for health promotion interventions in targeted populations. In our study, we investigated the prevalence of IPIs and the predisposing factors among children and adolescent students with intellectual disability in Hamadan. Prevalence was 42.5\% (95\% confidence interval 37.1-47.9, which is higher than findings reported during the past decade from other parts of the country, including Urmia (20.4\%) in the north west, Mazandaran province $(26.2 \%)$ and Rasht $(29.5 \%)$ in the north, and Ah$\operatorname{vaz}(33 \%)$ in the south $(9-12)$. However, it is lower than the $48.5 \%$ prevalence described in the intellectually disabled residents of a rehabilitation centre in Bandar Abbas, another area in southern Islamic Republic of Iran (13).

The difference between our findings and those of previous studies may be attributable to sample size, sampling strategy, method of stool examination, geographical area or study population. In other parts of the world there are relatively few estimates of the prevalence of IPIs in the mentally disabled population; examples include Egypt 43.5\%, Korea 35.7\% and Thailand $38.46 \%(16-18)$.

In our study, protozoal infections were common among the participants and intestinal helminthiasis was rare although enterobiasis was not investigated by the adhesive sellotape anal swab method. This finding is in accordance with the results of studies conducted in the north of the country $(10,11)$. The human dicrocoeliasis detected in our study is a spurious infection and must be ignored due to the consumption of raw liver from animals infected with $D$. dendriticum. Two decades ago, soil-transmitted helminth infections were one of the most common IPIs in the general population in Hamadan: prevalence of ascariasis was 19\% in 2001 (19). Development of health promotion and education programmes in this region has led to a reduction in IPIs, particularly helminthiasis (20).

A high frequency of multiple parasitic infections was another important finding: $12.3 \%$ were infected with $\geq 2$ parasite species. In our study, polyparasitism was significantly higher than in the other studies conducted in the Islamic Republic of Iran and in contrast with those studies, triple and quadruple infections were observed 
(9-13). These disparities may be a result of differences in the severity of contamination of the environment or the sensitivity of diagnostic methods. Ten species of intestinal protozoan and helminthic parasites were detected in the samples, the most common was B. hominis with a prevalence rate of $28 \%$. This is higher than rates reported in previous Iranian studies (9-13). Giardia lamblia was the second most common parasite observed in the students, with a prevalence of $9.7 \%$. This is similar to that observed in other studies conducted in Mazandaran province (10.2\%) and Ahvaz (9.4\%), and is slightly higher than those reported from Urmia (6.2\%), Rasht (4.6\%) and Bandar Abbas (6\%) (9-13).

Climate is one of the factors affecting the distribution of parasite species. Strongyloides stercoralis is a prevalent parasite in some areas with warm moist climates; it is reported in Bandar Abbas as the most common parasite (17.3\%) among people with mental retardation (13). In our study, S. stercoralis was not detected, and this is consistent with reports from studies conducted in Urmia, Mazandaran province and Ahvaz $(9,10,12)$.

We found that the infection was slightly more prevalent in females than males, but this was not statistically significant $(P=0.397)$. This finding is consistent with other studies that demonstrated sex was not a substantial risk factor for IPIs $(9-11,13,16,18)$. Age is another epidemiological factor that can affect the prevalence of IPIs $(9,12)$. A statistically significant correlation was observed between the age of the students and IPIs. But unexpectedly, the prevalence of the infection increased with increasing age. This conflicts with the studies that showed a negative correlation between older age and IPI rate $(9,12)$. This contradiction can be explained by the fact that parents and mentors are likely to be caring more for children than teenagers. The other risk factor investigated in the present study was washing methods of vegetables. Along with the study conducted in the north of the country, the results demonstrated consumption of raw vegetables could be considered as a risk factor for IPIs. Investigations of parasitic contamination of vegetables in Hamadan province confirm this finding, however infection can be significantly reduced by proper washing vegetables $(11,21,22)$.

One limitation of this study was the inability to detect enterobiasis and coccidiosis because identification of the parasite infections required specific methods.

\section{Conclusion}

Our findings show that the prevalence of intestinal protozoan infections among mentally disabled students is considerable in Hamadan. The high prevalence rate of the pathogenic parasites B. hominis and G. lamblia is a concern as they can cause further conditions affecting in mental and cognitive development in the students. Also it indicates the high potential for transmission of other intestinal microbes among them. Therefore, there is a need to promote preventive health care to raise awareness about the health and hygiene of mentally handicapped students.

\section{Acknowledgement}

The authors are grateful to the students and their families, the special school teachers, and the vice-chancellor of research and technology of Hamadan University of Medical Sciences for their cooperation in this study.

Funding: This study was supported by the Vice Chancellor of research and technology, Hamadan University of Medical Sciences (Project No. 9309255069).

Competing interests: None declared.

\section{Infection parasitaire intestinale chez les élèves atteints d'un handicap mental, République islamique d'Iran}

\section{Résumé}

Contexte : Les infections parasitaires intestinales comptent parmi les problèmes de santé publique les plus courants dans les populations dont l'hygiène est insuffisante. Par conséquent, le retard mental augmente le risque d'infection.

Objectifs : La présente étude avait pour objectif d'étudier la prévalence des infections parasitaires intestinales chez les jeunes présentant un handicap mental à Hamadan, dans l'ouest de la République islamique d'Iran.

Méthodes : Cette étude transversale descriptive a été menée auprès de 318 élèves de neuf écoles spéciales en 2017. Des échantillons de selles en triplicata pour chaque élève ont été soumis à analyse en utilisant la technique de montage humide direct, de concentration par sédimentation et de coloration permanente. Le test du khi carré et le test exact de Fisher ont été utilisés pour l'analyse statistique.

Résultats : Sur 318 élèves, 135 (42,5\%, IC 95\%: 37,1 à 47,9) étaient infectés par des parasites intestinaux. Les taux de prévalence chez les filles et les garçons étaient de 45,2\% (61/135) et 40,4\% (74/183) respectivement. Les infections à protozoaires $(42,5 \%, 135)$ ont été plus nombreuses que les helminthiases $(0,6 \%, 2)$. Blastocystis hominis $(28 \%$, 89) était le parasite le plus fréquent, suivi par Giardia lamblia $(9,7 \%$, 31), Entamoeba coli (9,1\%, 29) et Trichomonas hominis $(6 \%, 19)$. 
Conclusions: Le taux élevé de prévalence des infections intestinales à protozoaires reflète le manque d'hygiène personnelle des étudiants et des conditions environnementales inappropriées. Par conséquent, des mesures de santé publique spécifiques sont nécessaires pour les étudiants atteints d'un handicap mental dans les écoles spéciales.

\section{العدوى الطفيلية المعوية في صفوف الطلاب المعوَّقين ذهنيًا في جمهورية إيران الإسلامية}

مريم خضري، مينا بيري ، محمد متيني

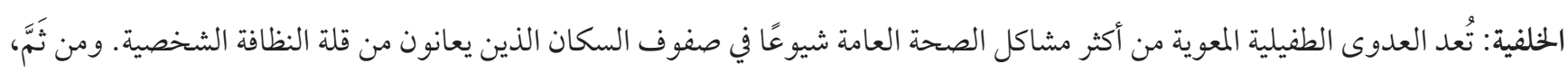
فإن التخلف العقلي يزيد من خطر العدوى العدئ.

الأهداف: هدفت هذه الدر اسة إلى استقصاء معدل انتشار العدوى الطفيلية المعوية في صفوف الأطفال المعوَّقين ذهنيًا في همدان، غرب جمهورية إيران الإسلامية.

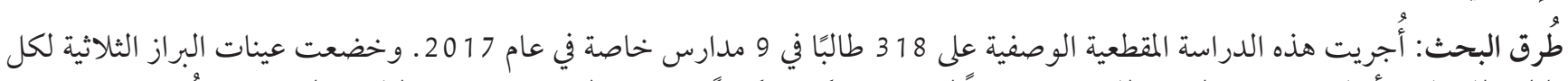

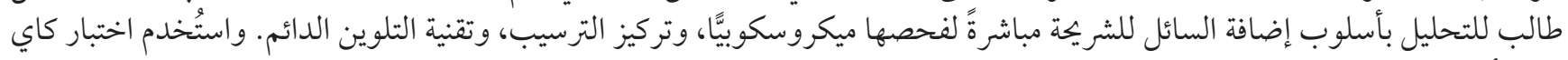

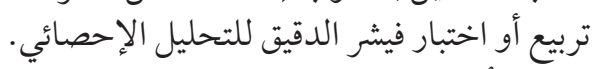

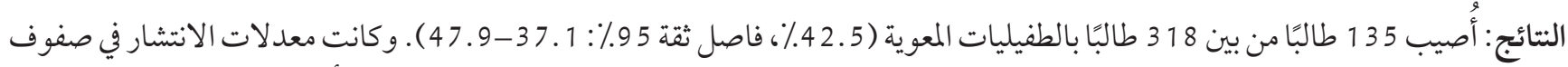

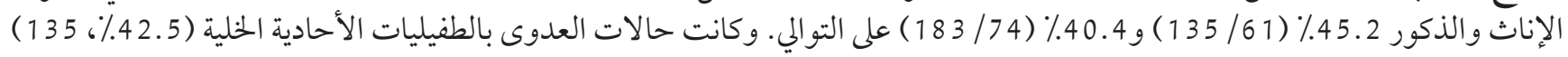

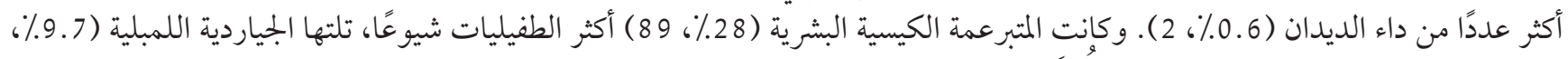

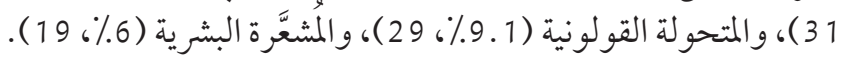

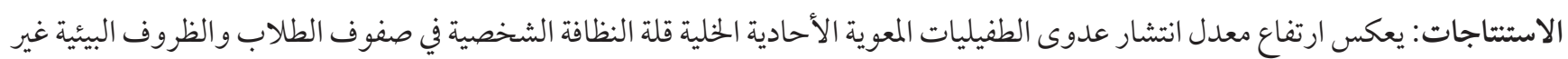

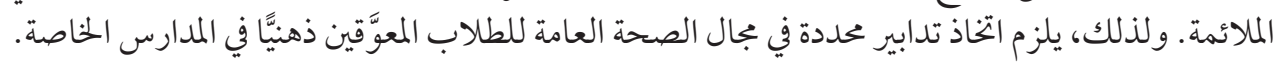

\section{References}

1. Partners for parasite control: geographical distribution and useful facts and stats. Geneva: World Health Organization; 2007 (http://www.who.int/wormcontrol/statistics/geographical/en/index.html, accessed 15 March 2007).

2. Berkman DS, Lescano AG, Gilman RH, Lopez SL, Black MM. Effects of stunting, diarrhoeal disease, and parasitic infection during infancy on cognition in late childhood: a follow-up study. Lancet. 2002;16;359(9306):564-71. doi:10.1016/So140-6736 (02)07744-9.

3. Stephenson LS, Latham MC, Ottesen EA. Malnutrition and parasitic helminth infections. Parasitol. 2000;12199(Suppl.):S23-38. PMID:11386688.

4. Alum A, Rubino JR, Ijaz MK. The global war against intestinal parasites--should we use a holistic approach? Int J Infect Dis. 2010;14(9):e732-8. doi:10.1016/j.ijid.2009.11.036

5. Koshak EA, Zakai HA. A spectrum of pathogenic and non-pathogenic intestinal parasites in pre-employment medical check-up for workers and their families. J Family Community Med. 2003;10(1):47-53. PMID:23011980

6. Tellez A, Morales W, Rivera T, Meyer E, Leiva B, Linder E. Prevalence of intestinal parasites in the human population of Leon, Nicaragua. Acta Trop. 1997;66(3):119-25. PMID:9210962.

7. Gamboa M, Basualdo J, Kozubsky L, Costas E, Rua EC, Lahitte H. Prevalence of intestinal parasitosis within three population groups in La Plata, Argentina. Eur J Epidemiol. 1998;14(1):55-61. PMID:9517874.

8. Naiman HL, Sekla L, Albritton WL. Giardiasis and other intestinal parasitic infections in a Manitoba residential school for the mentally retarded. Can Med Assoc J. 1980;122(2):185-8. PMID:7363211.

9. Tappeh KhH, Mohammadzadeh H, Rahim RN, Barazesh A, Khashaveh Sh, Taherkhani H. Prevalence of intestinal parasitic infections among mentally disabled children and adults of Urmia, Iran. Iran J Parasitol. 2010;5(2):60-4. PMID:22347245.

10. Sharif M, Daryani A, Asgarian F, Nasrolahei M. Intestinal parasitic infections among intellectual disability children in rehabilitation centers of northern Iran. Res Dev Disabil. 2010;31(4):924-8. doi:10.1016/j.ridd.2010.03.001.

11. Saeidinia A, Tavakoli I, Naghipour MR et al. Prevalence of Strongyloides stercoralis and other intestinal parasites among institutionalized mentally disabled individuals in Rasht, northern Iran. Iran J Parasitol. 2016;11(4):527-33. PMID:28127364.

12. Zand M, Farahnak A, Khalili M. Study of prevalence of intestinal parasites in mentally retarded in Ahvaz city, south Iran. Int Res J Basic Appl Sci. 2013;6(6):842-4. 
13. Shokri A, Sarasiabi KS, Teshnizi SH, Mahmoodi H. Prevalence of Strongyloides stercoralis and other intestinal parasitic infections among mentally retarded residents in central institution of southern Iran. Asian Pac J Trop Biomed. 2012;2(2):88-91. doi:10.1016/S2221-1691(11)60198-6.

14. Uchôa FFM, Sudré AP, Macieira DB, Almosny NRP. The influence of serial fecal sampling on the diagnosis of giardiasis in humans, dogs, and cats. Rev Inst Med Trop Sao Paulo. 2017;59:e61. doi:10.1590/S1678-9946201759061.

15. Garcia LS (). Diagnostic medical parasitology, 5th ed. Washington, DC: ASM Press; 2007.

16. Shehata AI, Hassanein F. Intestinal parasitic infections among mentally handicapped individuals in Alexandria, Egypt. Ann Parasitol. 2015;61(4):275-81. doi:10.17420/ap6104.19.

17. Lee J, Park GM, Lee DH. Intestinal parasite infections at an institution for the handicapped in Korea. Korean J Parasitol. 2000;38(3):179-81. doi:10.3347/kjp.2000.38.3.179.

18. Rhongbutsri P, Saichua P, Navaphongpaveen K, Taylor A, Leelawongtawongtawon R, Kitvatanachai S. Intestinal parasitic infections in students at a school for handicapped children in Khon Kaen Province, Thailand. Thammasat Med J. 2010;10:406-10.

19. Falah M, Azimian MH, Nabiee M, Hojati M. Epidemiological study of ascariasis in Hamadan city, west of Iran, 2001. Sci J Hamdan Univ Med Sci. 2004;11(1):55-60.

20. Fallah M, Mirarab A, Jamalian F, Ghaderi A. Evaluation of two years of mass chemotherapy against ascariasis in Hamadan, Islamic Republic of Iran. Bull World Health Organ. 2002;80(5):399-402. PMID:12077616.

21. Matini M, Shamsi-Ehsan T, Maghsood AH. (2014). The parasitic contamination of farm vegetables in Asadabad city, west of Iran, in 2014. Avicenna J Clin Microb Infec. 2014;4(1):e32474.

22. Rahmati K, Fallah M, Maghsood AH, Shamsi-Ehsan T, Matini M. The prevalence of parasitic contamination of vegetables consumed in Malayer city, west of Iran, in 2014. Avicenna J Clin Microb Infec. 2014;4(1):e32474. 